\title{
AN OVERVIEW OF ALBERTA'S RECENT LEGISLATION ON NATURAL GAS ROYALTY SIMPLIFICATION AND GAS STORAGE
}

\author{
GLEN ACORN` and MICHAEL W. EKELUND“*
}

\begin{abstract}
The gas industry is a primary source of revenue for the Alberta government. However, calculating and collecting revenues was creating significant difficulties for the Department of Energy and the industry. The authors take a detailed insider's look at Alberta's new royalty regulation - the pressures that led to its development, the time constraints that helped shape it and the problems it is designed to solve. An insightful analysis of how related legislation settles ownership of storage rights in underground formations concludes the article.
\end{abstract}

\section{TABLE OF CONTENTS}

I. THE GAS ROYALTY SIMPLIFICATION PROJECT $\ldots \ldots \ldots 342$

A. GOVERNMENT-INDUSTRY NEGOTIATIONS

ON THE NEW ROYALTY SYSTEM . . . . . . . . . 342

B. DRAFTING AND THE CONSEQUENCES

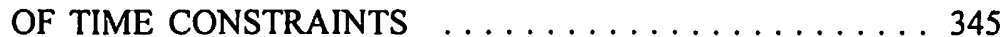

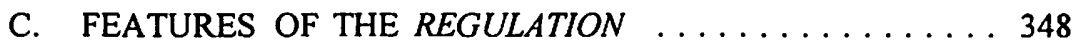

II. GAS STORAGE RIGHTS $\ldots \ldots \ldots \ldots \ldots \ldots \ldots \ldots$

\section{THE GAS ROYALTY SIMPLIFICATION PROJECT}

\section{A. GOVERNMENT-INDUSTRY NEGOTIATIONS ON THE NEW ROYALTY SYSTEM}

\section{Introduction}

Some aspects of the Natural Gas Royalty Regulation, $1994^{1}$ can be understood only by having some knowledge of the events that led up to its enactment under the Mines and Minerals $\mathrm{Act}^{2}$ in December 1993. As will be seen, the Regulation can still be viewed as a work in progress.

From 1974 to 1993, the Crown's gas royalty system was embodied in the Natural Gas Royalty Regulation, ${ }^{3}$ now retitled as the Natural Gas Royalty (Pre-1994) Regulation. ${ }^{4}$ The Pre-1994 Regulation began life in 1974 as a relatively simple

- Barrister and Solicitor, Edmonton. Mr. Acorn was the principal drafter of the legislation.

-. Executive Director, Royalty and Tenure Policy, Alberta Department of Energy, Edmonton. Mr. Ekelund, a professional engineer and lawyer, was a negotiator and policy team leader for the department in negotiations with industry that lead to the legislation.

$1 \quad$ Alta. Reg. $351 / 93$ [hereinafter Regulation].

2 R.S.A. 1980, c. M-15.

3 Alta. Reg. 246/90 [hereinafter Pre-1994 Regulation].

$4 \quad$ Alta. Reg. 252/93. 
legislative scheme but over the years it was patched extensively to meet changing conditions until it became unwieldy. The amendments over the years for the most part reflected extensive changes in the Department of Energy's gas royalty administration system designed to keep up with the increasing complexity of the natural gas marketing business.

In the late 1980s, the department came under pressure to change the system. There had been recurring criticisms in the annual reports of the Auditor General of Alberta that the department's administrative system was inadequate in ensuring that the Crown royalty share of gas and products had been fully traced and paid for. Despite changes to the system, the complexity of the business continued to generate the same problems. Industry groups believed that the royalty reporting system had become unacceptably burdensome and was in need of a major overhaul.

The royalty reporting system had developed in a regulated market of long-term contracts tied to reserves with sales at the processing plants. Once the marketing of gas was deregulated in 1986, considerable sales were being made downstream and not tied to particular reserves, the number of facilities and producers was growing and gas products were increasingly being injected for new purposes. By 1991, royalty reporting required a detailed breakdown of costs and revenues at approximately 16,000 points. Four sets of accounting records were required: (1) allocation of production to owners of individual wells; (2) valuation of gas and gas products at the point of sale (sometimes as far away as the southern United States) by each "royalty client"; (3) determination of the Crown's share of gathering and processing costs at each gas processing plant, compressor and pipeline gathering system; and (4) allocation of injected gas and gas products to each royalty client. There were 200,000 filings with the department each year, with another 250,000 amendments to the original filings.

Recognizing the system's problems, the department and Calgary-based industry associations entered into discussions in 1990 and 1991. Several minor fixes were reviewed but rejected as inadequate to significantly reduce complexity.

In 1991, the department engaged a management consulting firm to review the gas royalty system. With the help of department officials, the review involved interviews with industry and department personnel and was aimed at identifying changes that would simplify the reporting system. The principal conclusion arising from the review was that simplifying the reporting system would not by itself achieve substantial and universal simplification. What was needed was a complete overhaul of the fundamentals of the royalty system.

\section{Simplification Project Phase I}

In November 1991, the department and the industry embarked on the first phase of what became known as the "Gas Royalty Simplification Project". They identified the principal problems as too many filings, too many retroactive adjustments, onerous tracking of gas volumes from the well to the burner tip, and increasing complexity in valuing gas and gas products. Early on, the objectives were to develop a system that 
would reduce the industry's and the department's administrative costs by 50 percent and filings by 70 percent, to minimize amendments, reduce reliance on department audits, and maintain both an acceptable redistribution of royalty liability and an acceptable level of allowable Crown costs.

The agreed-upon objectives, however, had some significant constraints. The department realized, on the basis of the review, that if simplification was to be achieved by the adoption of averages for prices and allowable costs without additional cost to the Crown, the distributional impact of the new system would be too great to achieve broad agreement within the industry. The department and the industry agreed on two basic guidelines: that the new system have a positive impact or minimal negative impact on at least 70 percent of royalty clients; and that no company should be put out of business solely because of the changes.

The analytical work and development of the new system was conducted by a working committee consisting of representatives from the department and industry, including those from industry associations now known as the Canadian Association of Petroleum Producers, the Small Explorers and Producers Association of Canada and the Canadian Association of Petroleum Production Accountants. The "Phase I Report" of this working committee was completed in July 1992. It included recommendations for fundamental changes to the system, including the use of an average price for gas on which to base royalty liability and averages on which to determine the Crown's share of gathering and processing costs. The plant gate would become the place where the Crown's royalty share would be considered sold for royalty purposes. The report estimated the potential cost to the Crown, in terms of reduced royalty revenue, to be in the range of $\$ 35$ million annually.

At the same time, the department conducted a fiscal review of gas economics and of the gas royalty regime, which in turn led to major changes in the royalty system enacted by the government in October 1992. These changes included a reduction in the royalty rate on "new gas" (generally, gas discovered after 1973) to help provide cash flow to the industry for investment, thus alleviating the cash shortage attributable to the natural gas supply bubble at the time. The reduction in royalty revenue was forecast to be $\$ 85$ million for 1993 .

For 1994 , the benefit to the industry was also proposed to be at least $\$ 85$ million, but provided in a different way. The royalty rate was to be adjusted to provide a reduction of approximately $\$ 60$ million. A further royalty reduction, worth an expected $\$ 25$ to $\$ 35$ million, was to be provided through different methods of calculating royalty payments under the new system. The most financially significant of the changes are discussed below.

The new system was to use a prescribed average price to establish the value of the Crown's royalty share of gas. The use of an average price would prejudice those producers selling gas at prices below the prescribed average, just as it would benefit those selling gas at prices above the prescribed average. The major change proposed to minimize this uneven impact was a provision allowing a producer the alternative of 
valuing the Crown's royalty share of gas at the producer's own "corporate average price" instead of at the prescribed average price or "reference price". This flexibility was identified as having the largest potential impact on royalty revenues.

A second change involved removing the restriction on allowable costs to a maximum of 95 percent of the royalty value of gas sold from each reporting entity by each contract. This provision not only kept administration at a very detailed level, but in some cases it placed disproportional costs on industry.

A third change was the replacement of the royalty valuation minimum price of 80 percent of the Alberta Average Market Price ("AMP") with a minimum of 90 percent of the reference price. This was a benefit as many companies had some very low-priced sales.

The department and the industry are expected to realize significant savings in administrative costs attributable to the simplification of the royalty system. Industry savings are estimated at $\$ 20$ million per year.

\section{Simplification Project Phase II}

The working committee proceeded to the second phase of the project, that is, the definition and implementation of the new rules for natural gas royalty and the overhaul of the royalty regime for natural gas liquids and sulphur.

The efforts of the working committee led to the completion of a joint industrydepartment report dated May 12, 1993, embodying the new rules and principles for the new royalty system and the key analytic variables used in determining the distributional impact of the new system on the industry. This report, entitled "Gas Royalty Administration 1994: Program Design", formed the basis for subsequent draft versions in June, September and November 1993 of the new gas royalty guidelines and the current version, dated June 30, 1994 entitled "Alberta Natural Gas Royalty: Principles and Procedures: 1994". For convenience, this later version and its predecessors will be referred to as the "Guidelines".

\section{B. DRAFTING AND THE CONSEQUENCES OF TIME CONSTRAINTS}

Drafting began in mid-July 1993, with the first draft being based on the then current version of the Guidelines. The drafting was completed on December 13,1993 - one day before the Regulation was approved by Cabinet. Five months was barely enough time to complete the drafting and, as indicated earlier, the Regulation is still not really complete.

Drafting the Regulation had its own peculiar problems, but time, or the lack of it, was the most formidable. The time constraints had an unusual effect on the text of the Regulation and on the circumstances of its enactment. 
As detailed negotiation moved toward completion, it became necessary to choose whether to implement the new system in January 1994 or in January 1995. The industry opposed implementation of the new system in mid-year. While the department was prepared to postpone the starting date to 1995 , industry representatives and associations, anxious to enjoy the benefits of the system sooner rather than later, pressed the government to put it in place in January 1994. The government's decision to accede to the industry's wishes on the start-up time had some consequences for the Regulation itself. Some aspects of the Regulation can only be understood in the context of this decision and the process that followed.

The formulation of the Regulation proceeded on two tracks. The department negotiated the drafting of the Guidelines with industry representatives. The drafts of the Regulation were negotiated with Department officials only; the drafts were not reviewed by, let alone negotiated with, industry representatives primarily because there was insufficient time to do so if the task was to be completed before January 1994. The details of the new royalty system were being refined as the drafting process and the negotiations progressed.

As fall approached, it became apparent that fleshing out details of many essential features of the new system in the Guidelines, let alone in the Regulation, would be impossible if the new system was to be in place by January 1994. It was also apparent that the department's computer system, as well as those of most, if not all, companies in the industry, would not be ready to accommodate the new system by January 1994 .

The following paragraphs describe some aspects of the Regulation that were the direct result of, or influenced by, the decision to bring it into force on January 1, 1994.

\section{Essential Features of the System in the Guidelines}

As with previous regulations, the Regulation never mentions the Guidelines as such. They have existed in the past as the administrative rules embodying the Minister's exercise of discretion found in the Regulation. Allowable processing cost claims are a good example of this in both the old and the new system. Section 17 (section 28 in the Pre-1994 Regulation) makes the Crown liable for costs incurred in processing, gathering and reprocessing the Crown's share and to which the minister consents. The minister is given the power to determine the amount of those costs. Upon that basis a detailed set of rules regarding cost eligibility has been included in past guidelines.

The Regulation also makes several references to ministerial directions. Under most of these provisions, the Minister's directions are embodied in the Guidelines but could presumably be contained in a separate document, such as a departmental information letter or information bulletin distributed to the industry. 
One important example of a ministerial direction relates to "associated" persons. 5 Whether or not two or more persons are "associated" depends on the rules in the Guidelines. The association rules in turn are critical for a producer (or royalty client) who elects to pay royalty compensation on the basis of the client's "corporate average price" ("CAP"). Ministerial directions expressed in the Guidelines also determine how a client's CAP for a year may be recalculated.

It was recognized that the subject-matter of many of these ministerial directions in the Guidelines should be in the Regulation itself. Even as drafts of the Regulation were being prepared it was recognized that details regarding these topics could not be settled in time to be included in the Regulation. The plan is to eventually put them in the Regulation.

\section{The Two-Year "Sunset Clause"}

The industry representatives, while recognizing that details of some essential features of the system would necessarily have to be relegated to the Guidelines if the system were to be in place in January 1994, nevertheless wanted the situation to be corrected eventually by having these features dealt with in the Regulation itself. This led to agreement on the inclusion in the Regulation of the two-year "sunset clause" in subsection $30(2)$ which reads:

(2) Subject to sections 28 and 29, this Regulation applies only to natural gas recovered, and gas products obtained, in the production months commencing with January, 1994 and ending with December, 1995.

It is expected that the Regulation will be amended or re-enacted, effective January 1,1996 and will incorporate detailed provisions on subjects that are now dealt with as "directions" in the Guidelines.

3. The Need For Estimated Payments in the Initial Months

Prior to the "Operational Month"

Paragraph 15(6)(a) empowers the Minister to specify a month in 1994 as the "operational month". The decision to name the operational month will signal that the department's computer system is ready to accommodate the new royalty system and that the industry associations have agreed that most if not all companies' computer systems are ready as well.

For the months preceding the operational month, the royalty system works on the basis of estimated amounts of royalty compensation owing. Once the operational month arrives, the department will invoice royalty clients for each of the preceding months based on actual calculations of royalty quantities and compensation. 


\section{The Need for Statutory Validation}

When the government agreed with the industry's recommendation to start the new system in January 1994 instead of January 1995, the most difficult issue facing it was that some of the Regulation's essential elements were not authorized by the Mines and Minerals Act. ${ }^{6}$ The decision to enact the Regulation in December 1993 was taken with the realization that the Regulation would need to be validated by statute at the next session of the legislature. The validation provision is section 26 in the Mines and Minerals Amendment Act, 19947 which received royal assent on May 25, 1994.

The essential element of the Regulation that required statutory validation is the concept of automatic transfer of title of the Crown's royalty share of natural gas and gas products to the owner of the lessee's share, coupled with the obligation to pay "royalty compensation" to the Crown with respect to the royalty share so transferred.

Prior to the amendment, the Mines and Minerals Act provided for three kinds of royalty systems: delivery of the royalty share in kind (as is the case with crude oil royalty, at least until 1995); payment of a money royalty; or the imposition of an agency relationship under which the royalty client is made the Crown's agent to sell the Crown's royalty share and to account for the value of that share (the system in the Pre-1994 Regulation being the most notable example).

The concept of automatic transfers of title represented a significant change from the systems then authorized by the Mines and Minerals Act. It was fundamental to the viability of the Regulation because it embodied the agreement with industry that the Crown's royalty share of gas and gas products would normally be valued at the plant gate, drastically reducing the number of points in Alberta at which royalty quantities were calculated. In short, this fourth system was critical to the viability of the whole legislative scheme. Thus, if the new system was to be in place by January 1994, the Regulation could only proceed on the basis of the need for subsequent statutory validation.

\section{FEATURES OF THE REGULATION}

The natural gas business in Alberta is increasingly complex and past royalty regulations have mirrored as closely as possible the actual gas business. "Simplification" in this context means "simpler than it used to be." The Regulation still runs to seventy-six pages and the Guidelines are half an inch thick.

While the Regulation may not look any simpler than its predecessor, the royalty system it reflects is. This has been achieved through significant changes to the fundamentals of royalty administration. 
The following section is an overview of the most significant changes in the Regulation, with some background on the previous system.

The same basic structure of the previous system remains in the Regulation. This consists of four steps:

(1) The Crown royalty percentage is calculated at the wellhead for each "well event" (each separately measured producing zone within a well bore) based on a set of royalty formulas.

(2) The Crown royalty share of production is calculated for each "royalty client" (a person identified to the department as being responsible for the royalty obligations of a well event or group of well events). This is done by multiplying the royalty percentage by the volume of product produced at the point where it is first measured, generally just after processing. Production originating from royalty holiday well events is excluded.

(3) The Crown calculates its share of the cost of processing the natural gas, based on the Crown's share of the volume of gas entering a processing plant or gathering system.

(4) The Crown's royalty share of the gas products produced is valued on the basis of the market price of gas and products and processing costs are deducted. The royalty client then pays the royalty value, net of the processing costs.

1. Calculation of Royalty Quantities and Royalty

Compensation for Gas and Ethane

a. Royalty Formulas

The royalty formulas for gas and products have not been changed substantively. The royalty percentages for gas are dependent on the price of natural gas and the productivity of the well event. A minor change has replaced the department-estimated AMP with the Gas Par Price. This price is an actual after-the-fact calculation of average price for the previous month, the previous month's Reference Price.

The royalty formula for pentanes remains unchanged except for the replacement of "F" or "the average selling price of a cubic metre of pentanes plus for the month" in the Pre-1994 Regulation with the prescribed Pentanes Par Price for the month. At the very least, this change will avoid disputes over the calculation of the client's "average selling price". The Pentanes Par Price is the Pentanes Reference Price prior to transportation allowance deductions.

The royalty percentages for other products remain fixed (i.e. propane and butanes 30 percent, sulphur $-162 / 3$ percent). Ethane royalties are calculated as if the ethane was still in the gas stream. 


\section{b. Automatic Transfer of Title at the Plant Gate}

As mentioned earlier, a key change was to bring the valuation and processing cost transactions to a single point - the "plant gate". The point of valuation has been shifted from the point of actual sale to the plant gate by creating an automatic transfer of the Crown's title to its royalty share of gas and gas products to whomever is the owner of the lessee's share at this point.

The transfer point is normally the physical plant outlet meter since most natural gas is processed into residue gas. For natural gas consumed or disposed of without having first been processed ("raw gas") the transfer point is either the last point of measurement prior to its delivery from the gathering system or the point of delivery to a buyer if upstream from there.

The "automatic transfer of title" system drastically reduces the number of points where royalty compensation is calculated. Under the former system, royalties were calculated at approximately 16,000 points or "reporting entities" (commonly called "RENs"), with each one having the potential of sales under more than one contract. Under the new system, most transfers will take place at one of 600 plants, with one price applied across the province.

\section{c. Royalty Compensation at an Average Price}

The second key change is that when the transfer is made, the royalty client becomes liable to pay compensation to the Crown for that share at a specified price. The compensation for raw gas, residue gas and ethane is generally calculated using one of two prices, the monthly Gas Reference Price or the royalty client's CAP for the year. As of July 15, 1994, royalty clients responsible for over 85 percent of the gas production in the province have made a permanent election to use the Gas Reference Price.

For natural gas liquids there is only a reference price and for sulphur all compensation is calculated using the Sulphur Corporate Average Price.

Use of the Reference Prices simplifies the system by avoiding the disputes that arose under the Pre-1994 Regulation regarding calculations of the "selling price" of the Crown's royalty share, which could be sold anywhere in Canada or the United States. The CAP option maintains some of the complexity, as all sales must be included in the calculation and may be audited. However, much of the complexity of tracking individual sales back to individual well events, to ensure that high price contracts were not being allocated to low Crown interest wells, is removed.

Despite its complexity, the CAP option serves a useful purpose by limiting the impact of a provincial average price on royalty clients who consistently receive belowaverage prices for their gas. With the narrowing of prices between different markets that has occurred over the past two years, this is becoming less of an issue. 


\section{d. CAP and Reference Prices}

The option to use the royalty client's CAP to calculate compensation for gas and ethane may lead to disputes because of the somewhat elaborate eligibility rules for initially obtaining and then retaining the right to use it. Once the royalty client loses the right to use the CAP, the client cannot regain it and must thereafter use the Gas Reference Price. Because of the serious effect of these eligibility rules, they have been included in the Regulation rather than in the Guidelines.

The calculation of the CAP for gas and for sulphur, as well as the calculation of the Reference Prices, are set out in the Guidelines.

The royalty client's gas and ethane CAP is determined annually on the basis of the client's sales to non-associates (normally valued at the netback value at the plant gate), the client's sales to associates (valued at the CAP of the associate) and the client's use of product for injection or other consumption, valued at the relevant prescribed Reference Price for the month. Generally speaking, one corporation is associated with another if one owns 75 percent of the shares of the other.

The Gas Reference Price is calculated using a weighted average of all large sales of natural gas. The information is collected under provisions of the Natural Gas Marketing Regulation $^{8}$ issued under the Natural Gas Marketing Act. $^{9}$

Prices are reported for all sales made beyond Alberta's borders by the company removing the gas. Sales to non-associates are included in the calculation of a weighted average price at each border point and sales to associates are valued at the weighted average for that point. Intra-Alberta prices are reported by major end-use purchasers, as defined in the Natural Gas Marketing Regulation. To obtain the Reference Price, an average intra-Alberta transportation deduction is made, as well as a deduction (the Value Point Adjustment) to account for the change in the price-reporting location from plant gate to end user and a deduction for costs incurred by netback contract aggregators that were deductible under the previous system.

A difference between the Gas Reference Price and CAP is that liquid ethane sales must be included in CAP, but are not included in the Gas Reference Price at this time.

The Regulation provides a further alternative for calculating royalty compensation that is limited to a small number of pre-existing long-term contracts or so-called cogeneration contracts. If the royalty client does not use CAP pricing and meets a considerable number of other eligibility requirements in the Regulation and in the Guidelines, the royalty client is able to calculate the royalty compensation for the Crown's share of gas sold under the contract based on the contract price. 
Royalty compensation for propane, butanes and pentanes plus is calculated starting with average prices for purchases in the Edmonton area each month. These prices respectively make up the Propane Reference Price, the Butanes Reference Price and the Pentanes Reference Price (for pentanes, forty degree API crude oil postings are used where a pentanes price is not available). Three prescribed allowances for the same month are deducted from the Edmonton prices. These are a Transportation Allowance for whichever of four regions is applicable, a natural gas liquids transportation-related Storage Allowance and a Fractionation Allowance where the product was obtained as a separate product by fractionation of a gas liquids mix downstream from a gas processing plant or reprocessing plant or a gathering system from where the mix came.

The method of calculating the royalty compensation payable in respect of the royalty share of sulphur is now quite different. Under the Pre-1994 Regulation, the royalty share was normally valued at the selling price when sold. Often sulphur inventories would remain unsold for many months or years, thus delaying the liability to pay. The new system makes compensation payable on production, calculated using the royalty client's annual corporate average price ("S-CAP"). This reduces disputes over selling prices and avoids long delays in royalty payments.

The royalty client's S-CAP is net revenues from the client's sulphur sales for the year divided by the number of tonnes sold. In some cases, the client will use a Sulphur Reference Price rather than its S-CAP to calculate the compensation. The first case arises where the client refuses to consent to or to cooperate in a departmental audit of the records relevant to its S-CAP calculation. In that case, the Minister may direct the client to calculate the compensation on the basis of the Sulphur Reference Price for that year and each subsequent year, with no chance to return to the use of the S-CAP. A second case arises where the client's non-associate sales for the year are less than ten percent of the client's total production for that year. The Sulphur Reference Price is the weighted average of all S-CAPs reported for the year.

\section{Allowable Costs Borne by the Crown}

Section 17 of the Regulation dealing with allowable costs appears similar to its predecessor, the gas cost allowance ("GCA") in section 28 of the Pre-1994 Regulation. However, the method for calculating allowable costs is quite different and markedly simpler to administer. The new method is dealt with almost entirely in the Guidelines.

In general terms, costs and allowances for gathering, compressing and processing the Crown's royalty share ("allowable costs") are classified as capital cost allowances, operating cost allowances and custom processing allowances.

Under the pre-1994 guidelines, royalty clients reported their actual incurred costs and calculated allowances in each of these categories for each reporting entity at each of $12,000 \mathrm{GCA}$ facilities. A facility could be a plant, a gathering system, a compressor, dehydrators, a sales pipeline, or even a piece of road. 
In the new system, operating costs are calculated by multiplying each volume of Crown royalty share inlet gas at a gas plant by a "unit operating cost". The unit operating cost is calculated in one of two ways.

Most plants have been categorized into one of five types based on the quality of gas being processed. An average unit operating cost has been calculated for each plant type and their related gathering systems, compressors, etc. Using the prescribed unit rate for the plant type removes much of the accounting previously needed.

The largest thirty-eight plants in Alberta (those with capacity of over $30,000,000$ cubic metres of gas per day) will continue to report their actual operating costs.

Capital costs for each plant are recorded by the owner of the capital. The capital allowance, which includes allowances for rate of return and depreciation and an adjustment for custom processing income, is calculated for each owner who is a royalty client using the total of the owner's capital and the owner's average Crown royalty share (the Corporate Effective Rate). This rate is the sum of the value of Crown royalty share for which the owners are responsible divided by the sum of the value of the products for which the owners are responsible.

Custom processing fees paid by a royalty client generally continue to be claimed by that client as paid, as under the previous system.

\section{Injected Gas and Gas Products and the Abolition of \\ Royalty-Paid Banks and Royalty Inventories}

Under the previous system, when gas or gas products on which royalty had been paid were injected into a pool, the royalty quantities were accounted for in a so-called "royalty-paid bank". When production from the pool exceeded the injected quantities, the Crown was bound to waive the royalty on the production to the extent of the amount on the bank, with a consequent deduction from the total in the bank. Conversely, when injected quantities exceeded production, the amount in the bank increased. Over time the administration of royalty-paid banks became a major burden, so the Regulation provides for a method of phasing them out.

Under section 28, the amount in each bank is determined as of December 31, 1993 and then amortized over a seventy-two month period, that is, divided into seventy-two equal monthly amounts commencing with January 1994. For each month in the seventytwo month period the department establishes a "royalty bank credit" for gas and for each gas product by calculating the royalty compensation that would be payable in respect of the gas or the gas product if the monthly amortized quantity were the Crown's royalty share of the gas or the product.

In the case of residue gas, for example, this would entail multiplying the amortized quantity for the month by the Gas Reference Price for the month. The royalty bank credit for the month is then credited to the royalty client's royalty account, unless the department chooses to pay the credit in cash. In some cases where the total of the 
royalty-paid is sufficiently small, the department may choose to calculate one royalty bank credit for January 1994 only and thus get rid of the whole bank at one stroke.

As indicated earlier, liability for the payment of royalty dollars under the Pre-1994 Regulation was triggered by a sale or other disposition of the gas or gas product. There were no limits on how long this liability could be deferred (particularly in the case of sulphur) except where natural gas, residue gas and ethane had remained unsold in storage for twelve consecutive months. In the latter case, the liability to pay the Crown the "fair value" of the gas was triggered at the end of the twelfth month as though the gas had been sold in the that month. As with royalty-paid banks, the administration of a multitude of royalty inventories was costly and burdensome. The Regulation provides for a phasing-out of the royalty inventory system for a new and simpler approach in dealing with injected gas and gas products.

Under section 29 of the Regulation, the department determines the total quantities of gas and gas products in each client's royalty inventory as of the end of December 1993 and then amortizes the total over a twelve-month period commencing January 1994. For each of the twelve months in 1994 the client is liable to pay compensation in respect of the monthly amortized quantity as though the amortized quantity were the Crown's share of gas and gas products recovered or obtained in that month. If the royalty inventory is sufficiently small the department may, except in the case of sulphur, choose to skip the twelve-month amortization in favour of treating the whole royalty inventory as having been produced in January 1994 and imposing liability for royalty compensation on the client accordingly.

If the royalty inventory includes sulphur, the department will treat the whole sulphur inventory as though it were obtained by processing in 1994 and impose liability for royalty compensation accordingly after the end of the 1994 production year.

Section 16 of the Regulation provides for a new approach to injected royalty quantities. Whenever gas or a gas product is injected in a month into an underground formation other than part of a commercial storage scheme, the department establishes an "injection credit" for the royalty client for that month. An injection credit for a month is calculated by first determining the Crown's royalty share of the injected quantities that would be payable if the injected quantities had instead been recovered or obtained from the receiving reservoir in that same month. Thus, the Crown-freehold ownership split for the pool is a significant factor. Then the department calculates what the value of royalty compensation would have been on that royalty share. This latter amount is the injection credit which, as its name suggests, is credited to the client's royalty account.

When the injected quantities are eventually produced they will, of course, be subject to the royalty for the month in which they are produced. In most cases the credit on the injection will be close to the royalty payment eventually made on production, with the Crown losing the time value of the credit amounts but obtaining the benefits of price increases over that period. 
The injection credit is paid on a gross royalty basis, that is, before deduction of allowable processing costs. As a volume of gas is produced, processing costs are allowed, and if it is reproduced after being injected, processing costs are again allowed. Due to this potential for double collection of costs, industry and the department agreed to a "clawback" of twice-collected costs in enhanced oil recovery schemes. The department will monitor the injection credit system to determine if it remains neutral in cost compared to the previous system. If not, the department will consider implementing a more complex, but revenue neutral, "net" injection credit.

When gas or gas products are injected for storage under a commercial storage scheme, no injection credits are given. Commercial storage no longer results in a deferral of royalty liability. Under the new system, royalty compensation will have normally been paid previously in respect of quantities going into storage.

The Natural Gas Storage Committee, a department task force reviewing all rules regarding gas storage, currently proposes that the Crown royalty volume of native gas in a commercial storage reservoir be purchased by the scheme operator. This could be done as a single payment, or amortized over ten years. Some rights of the Crown and the operator to revise the Crown royalty volume as new information is known would be included. The committee also proposes that the criteria for production based storage (i.e. not commercial) would be reservoirs where injection is taking place for enhanced oil recovery, cycling to increase liquids recovery, or for pressure maintenance and where there is no storage for compensation or for or by a gas distributor. All other reservoirs with gas injection would be considered commercial storage schemes.

\section{The Billing and Reporting Systems}

After the operational month arrives, the department will send a royalty invoice to each client in respect of each month. This is a complete reversal from the old system under which the client initially paid an estimated amount of royalty dollars owing and, by the end of the third month following the production month, furnished a royalty return based on a calculation of the actual amount owing and paid any amount in excess of the original estimate. The old system involved various reports and forms going back and forth between the department and the companies in an effort to account for "unreconciled volumes" and for royalty dollars still owing. This system was also accompanied by a complex system of pecuniary penalties for failure to reconcile volume discrepancies.

Under the new system, the department will prepare its invoice for a given production month on the basis of its calculations of actual royalty quantities. The invoice must be sent on or before the sixtieth day following the end of the relevant production month, by which time the minister will have prescribed the various reference prices, par prices and allowances for that production month.

An invoice is subject to subsequent adjustments based on more accurate data received afterward. If the royalty client objects, the invoice is subject to recalculation 
under section 39.01 of the Mines and Minerals Act. ${ }^{10}$ After the end of the year, the department must complete a recalculation of royalty and royalty compensation for all production months in the year. It is expected that the new billing system will substantially reduce administrative costs for the industry.

The production reporting requirements for the industry are much less extensive under the new system than under the old system. It is in this area, along with the use of reference prices, that most simplification has occurred in terms of administrative cost savings.

The department-industry negotiations sought to formulate a system of standard royalty reporting that meshed with the system of royalty allocations already in use. The most important document in this reporting system is the "owner activity statement" ("OAS"), filed monthly by facility operators such as operators of reprocessing plants, gas processing plants, pipeline gathering systems or gas batteries. This order for listing facilities is significant to the scheme of allocating quantities of gas or gas products (known as "quantities available for sale" in the Regulation) back to the well events or groups of well events ("well groups"). Eventual allocation back to the well groups is all-important as this is where particular royalty attributes, such as the Crown's percentage interest in the well group, are determined.

The Regulation imposes liability for royalty compensation on the client and in the last resort on the Crown's lessee. In very general terms, the client is the person who accepts the responsibility for paying the royalty compensation in respect of any given royalty quantity. Every well group has its royalty client. If royalty quantities are attributable to a given well group, it is the well group's royalty client (which may be one or more persons) who is pegged with the liability. First, however, the quantities must be "allocated down" to the well group level. This is done by owner activity statements. The order of facilities represents a chain for the purpose of allocation:

(1) reprocessing plants (other than field straddle plants);

(2) gas processing plants;

(3) gathering systems;

(4) gas batteries; and

(5) well groups (royalty clients).

In a very general way, the allocation system works something like a game in which a person who is caught out becomes "it", that is, the person responsible for paying the royalty. For example, the operator of a reprocessing plant may allocate production down to one or more royalty clients for the relevant well groups (i.e. the source of the gas reprocessed) but to the extent that the operator does not do so, the operator must allocate the remainder of the production to operators of the gas processing plants, gathering systems or gas batteries from which the gas was delivered. Similarly, a gas processing plant operator may allocate production down to royalty clients at the well 
group level but must allocate any remainder to the operators of the gathering systems or gas batteries from which the production was received. Gathering system operators must allocate down to operators of other gathering systems or gas batteries that delivered gas to them. Operators of gas batteries must allocate all of their production down to royalty clients at the well group level because there is no one else below them in the chain.

If one operator allocates production down to another operator in the chain, that other operator must allocate that production down as well as any other production for which the operator is "responsible" because of subsection 2(6) of the Regulation. Allocations can never be made "up" in the chain. If a facility operator fails to file an owner activity statement for a month by the deadline, the operator is deemed by subsection 21(8) to have filed an OAS showing no allocations of production. If all goes as it should, all production for the month in the chain will be allocated down to royalty clients at the well group level and Crown royalty can then be calculated on the production.

If a facility operator fails to allocate all or some of the production in accordance with the system described above, the following happens under subsection 22(2):

(1) the unallocated quantities of natural gas are deemed to be recovered pursuant to Crown leases and the unallocated gas products are deemed to be obtained from natural gas recovered pursuant to Crown leases;

(2) the unallocated quantities are deemed to be allocated to the facility operator;

(3) the facility operator is deemed for the purposes of the Regulation to be the royalty client with respect to the Crown's royalty share of those unallocated quantities; and

(4) the facility operator, in the capacity of a royalty client, must pay to the Crown royalty compensation in respect of the Crown's royalty share of those unallocated quantities, calculated in accordance with subsection 22(4).

Subsection 22(4) prescribes the manner of calculating "provisional royalty compensation" on the unallocated production based on a deemed royalty rate of 35 percent and on the relevant prescribed Reference Prices, with no reduction for allowable costs. These amounts are called provisional royalty compensation because the operators can, by filing new or amended owner activity statements, deal with the unallocated quantities so that all will be properly allocated. The severity of the provisional royalty compensation is aimed at encouraging timely and accurate allocations.

Similar approaches are taken in subsections (2) and (3) of section 22 where the production quantities for a month reported by a facility operator to the Energy Resources Conservation Board exceed the operator's OAS allocations for the month, or where the quantities shown in an operator's OAS statements as purchased in a month exceed the aggregate quantities sold in the same month according to OAS statements 
filed for the same month by upstream operators. In both cases, the excess quantities are subject to provisional royalty compensation, just as unallocated quantities are.

Injected quantities are not incorporated into the allocation scheme although they are reported in owner activity statements. The quantities must be shown in the statement as injected into a well group to calculate the injection credit and, in the case of commercial storage, to ensure the Crown can continue to balance the totals of production and disposition needed to verify that all Crown volumes each month are properly accounted for.

The importance of timely filings of owner activity statements is also reflected in subsection 24(1) of the Regulation which imposes an automatic $\$ 1,000$ penalty where a facility operator files no OAS statements of any kind by the deadline, the forty-fifth day after the end of the relevant production month. There are also automatic penalties of $\$ 1,000$ per month for late filing of a number of other reports and documents under the Regulation.

Subsections 24(5) to (7) of the Regulation provide for discretionary penalties where a departmental audit discloses an underpayment of royalty compensation for a year. The initial penalty is an amount equal to ten percent of the deficiency but whether or not a ten percent penalty is imposed in the first instance, the department must notify the royalty client describing "what in the Minister's opinion was the cause giving rise to the deficiency." If an audit for a subsequent year discloses another deficiency in royalty compensation and the department determines that the cause giving rise to the deficiency (such as a defective accounting practice) was the same as or similar to the cause described in the original notice, the department may impose a penalty of up to fifty percent of that part of the deficiency that it considers to be attributable to that cause. If the ten percent or fifty percent penalty, when calculated, is less than $\$ 1,000$, then no penalty can be imposed at all.

The rules for the calculation of interest are much the same as under the Pre-1994 Regulation.

Another novel aspect of the Regulation is the requirement in section 18 that each royalty client furnish a deposit to the department in an amount normally equal to onesixth of the aggregate of royalty dollars paid by the client for 1993. The deposit for new royalty clients will be calculated similarly on the basis of an estimate of two months' average royalty compensation.

Under the Pre-1994 Regulation, a royalty client had to pay the Crown an estimated amount of royalty dollars by the end of the first month following the production month, so the Crown had the use of the money from that time. With the implementation of the new system, the department prepares and sends the client a royalty invoice at the end of the second month following the production month, with payment required at the end of the third month. 
The rationale for deposits is that interest earned on the deposits (roughly two months' worth of royalty compensation) will keep the Crown in more or less the same position in terms of interest income that it had under the Pre-1994 Regulation.

\section{Other Novel Features}

Here, briefly, are some other features of the Regulation that are different from its predecessor:

(1) The status of solution gas (that is, gas recovered in association with crude oil production) is clarified under the new Regulation in section 1 which equates it with natural gas. Also "field condensate" is now defined as:

products obtained from natural gas or solution gas before it is delivered to a gathering system;

Therefore, if liquids are removed from gas before it reaches a gathering system, the liquids are field condensate and the royalty rate for field condensate is calculated under the Petroleum Royalty Regulation," as though it were crude oil. However, the royalty compensation payable in respect of field condensate is calculated on the basis of the Pentanes Reference Price less the Transportation Allowance applicable to a natural gas liquids mix.

(2) The rules in section 12 for certain exemptions from royalty related to gas or gas products consumed in field operations are slightly different from those in the Pre-1994 Regulation.

A policy change restricting royalty-free fuel gas consumed as fuel in commercial oil sands schemes to the remaining approvals made prior to January 1, 1994 was incorporated. Clarification of the pre-existing policy that this section does not apply to fuel gas sourced from field straddle plants, where the gas stream has been deemed sold prior to reprocessing, was also incorporated.

(3) The method for calculating royalty holidays in the new schedule of the Regulation has been changed from a net basis to a "grossed-up" basis.

Under the previous system, each well event or reporting entity was required to have price and processing costs allocated back to it by each contract. Therefore, the maximum value of the Crown's share of production on which the royalty holiday was allowed was specified in net dollars - gross value of the royalty share of production from that well event less the allocated processing costs. 
In the new system, a simpler method is used. The Crown's share of production reported on the OAS. will be valued at the applicable reference price or CAP and the maximum level will be restated on a gross basis using historical information on processing costs.

\section{GAS STORAGE RIGHTS}

Alberta's new gas storage legislation was also the subject of department-industry negotiations which were initiated as a result of proposals discussed in the Gas Royalty Simplification Project. The proposals involved a completely different approach to royalty liability in relation to gas and gas products injected for commercial storage. The proposals led to the provisions in the Regulation discussed in Part I, section C.3 of this article.

The legislation on this subject is contained primarily in section 54.1 of the Mines and Minerals Act, ${ }^{12}$ as amended by the Mines and Minerals Amendment Act, $1994 .{ }^{13}$ Other related amendments to the Mines and Minerals Act are as follows:

(1) the addition in subsection 1(1) of definitions of "fluid mineral substance", "storage rights", "subsurface cavern" and "subsurface reservoir";

(2) the addition of subsection 1(1.1) giving the minister the power to decide, for the purposes of the $A c t$ only, a question as to the purpose for which any given mineral or mineral product is injected into a subsurface reservoir, if a dispute on the matter arises between the minister and a Crown lessee or anyone claiming through the lessee;

(3) the addition of clause (ii.1) to paragraph 9(a) to permit the making of special Crown contracts related to the storage of substances in subsurface reservoirs;

(4) the addition of paragraph (a.1) in subsection 50(1) to permit inspections of wells used for injection of substances for storage purposes;

(5) an amendment to subsection 54(1) to make it subject to the new section 54.1;

(6) the addition of subsection (2) to section 55 to make it a "twin" of what is now renumbered as subsection 55(1), thus conferring on the owner of storage rights the right to drill through minerals in the same tract;

(7) the addition of subsection (2) to section 56 to provide a similar "twin" to what is now renumbered as subsection $56(1)$; 
(8) the re-enactment of subsection 146(1) to expressly permit a unit agreement to provide for a storage scheme; and

(9) the addition of subsection 149(2) to provide a "twin" to what is now renumbered as subsection $149(1)$.

Section 54.1 and the definition of "storage rights" refer to all "fluid mineral substances", which is defined as follows:

"fluid mineral substance" means a fluid substance consisting of a mineral or of a product obtained from a mineral by processing or otherwise;

At the very least, a "fluid mineral substance" extends to natural gas and to residue gas, ethane, propane, butanes, pentanes plus, a natural gas liquids mix and carbon dioxide obtained from natural gas.

"Storage rights" are defined in paragraph $1(1)(u .1)$ as follows:

"storage rights" means the right to inject fluid mineral substances into a subsurface reservoir for the purpose of storage;

It follows, or should follow, from the definition that storage is distinguishable from disposal because "storage" connotes an eventual recovery from the place of storage where "disposal" does not.

In section 54.1 and other new provisions, a distinction is made between an "underground formation", that is, a naturally occurring geological formation whether it contains petroleum or natural gas or not, and a "subsurface cavern", that is, a subsurface space created as a result of operations for the recovery of a mineral. Typically, a subsurface cavern is created in a solid salts formation by drilling a well into the formation and dissolving the salts by hydraulic methods. Usually, a subsurface cavern is used to store propane and butanes by a method involving brine displacement.

The expression "subsurface reservoir" is now defined in paragraph 1(1)(u.3) to mean either an underground formation or a subsurface cavern.

Here is the text of the principal provision, section 54.1:

54.1(1) Subject to subsection (2),

(a) where a person owns the title to petroleum and natural gas in any land, that person is the owner of the storage rights with respect to every underground formation within that land, and

(b) where one person owns the title to petroleum in any land and another person owns the title to natural gas in the same land, those persons are co-owners of the storage rights with respect to every underground formation within that land. 
(2) Where a person owns the title to a mineral in any land and operations for the recovery of the mineral result or have resulted in the creation of a subsurface cavem in that land, that person is the owner of the storage rights with respect to that subsurface cavern to the extent that it lies within that land.

(3) A person who has storage rights in respect of a subsurface cavern within any land has the right to recover any fluid mineral substance stored in that cavern, to the exclusion of any other person having the right to recover a mineral from the same land.

(4) In subsections (1) to (3), "person" includes the Crown in right of Alberta.

(5) Where the Crown in right of Alberta owns storage rights in respect of a subsurface reservoir, no person has, as against the Crown, any storage rights in respect of that reservoir except under

(a) a unit agreement to which the Crown is a party,

(b) a contract entered into under section 9(a), or

(c) an agreement issued with the authorization of the Lieutenant Governor in Council,

which expressly conveys storage rights in respect of that reservoir.

The principal purpose of subsection 54.1(1) is to settle the matter of ownership of storage rights in underground formations. The legal ownership of storage rights, or to the "spaces" in underground formations, has never been satisfactorily settled in Canada and there is a paucity of Canadian legal writing on the subject, let alone case law. The tendency in Alberta has been to assume that the ownership of storage rights lies with the owner of the minerals as distinct from the owner of the "surface", that is, the land excepting the minerals. Certainly, the storage arrangements that have been made with the Department of Energy and its predecessors over the past decades have proceeded on that assumption. The assumption has been based to a large extent on the state of the common law on the ownership of spaces left as a result of hard rock mining and coal mining. The law is reasonably well settled that these spaces belong to the owner of the mineral that was mined to create the space. ${ }^{14}$ The time for putting this ownership problem to rest was long overdue.

Paragraph 54.1(1)(a) confers storage rights in underground formations in land on the owner of the title to petroleum and natural gas in that land. If the title to the petroleum is owned by one person and the title to natural gas by another, paragraph 54.1(1)(b) confers the storage rights on those co-owners. It deliberately does not state the nature of the co-ownership as being joint or otherwise. In practical terms this means that a storage scheme cannot proceed in such a case unless both co-owners are parties to the contractual arrangements. It leaves the matter of compensation of each of them to 
negotiation. Subsection 54.1(1) does not go the whole way, that is, to provide for procedures similar to those for compulsory unitization by which recalcitrant title owners can be forced into participation in a storage scheme. If a storage scheme is to be conducted under a unit agreement, all title owners will have to be parties; there can be no "windows" in the unit area where unit operation is converted to a storage scheme.

Subsection 54.1(2) is intended to settle the matter of ownership of storage rights in subsurface caverns in favour of the owner of the mineral that was recovered by operations that resulted in the creation of the cavern. This situation provides a closer analogy to that of the owner of coal who owns the spaces created by underground coal mines. If the cavern happens to be within more than one tract, all of the mineral owners having storage rights in those tracts would be necessary parties to any storage scheme involving the cavern.

Neither subsection (1) nor (2) of section 54.1 attempts to state the law in retrospective terms. They proceed on the assumption that any attempt by the owners of the surface rights to seek compensation by reason of any alleged prejudicial effect of section 54.1 would not succeed. In other words, the section presupposes that, if the issue of storage rights ownership were to have been litigated, the courts would come to the same result that section 54.1 now achieves, that is, a result analogous to that involving the ownership of spaces resulting from mining.

Subsection 54.1(3) is included out of an abundance of caution. It is aimed at precluding any right by an owner of petroleum or natural gas rights to drill into a subsurface cavern and recover liquid hydrocarbons being stored in it. If the owner of the title to petroleum and natural gas in a tract containing a subsurface cavern is not also the owner of the title to the salts that were removed to create the cavern, the salts owner has the predominant storage rights in relation to the cavern and, by virtue of subsection (3), has the right, as against any other person, to recover fluid hydrocarbons from the cavern that the owner of the petroleum or natural gas rights might otherwise attempt to claim.

Subsection 54.1(4) is included simply to ensure that the Crown has both the benefits and burdens of the section in its capacity as a mineral owner.

Subsection 54.1(5) prescribes the three ways in which an interest in storage rights can be acquired from the Crown. The most common will be by way of a unit agreement to which the Crown is a party, as this has been the most common case in the past. Special Crown agreements under clause 9(9)(a)(ii.1) are expected to be rare. The third category, "an agreement issued with the authorization of the Lieutenant Governor in Council," and which expressly conveys storage rights, is also expected to be rare. It should be kept in mind that an "agreement" referred to in paragraph 54.1(5)(c) is a lease, licence or other document by which the Crown conveys a right to recover a mineral. Further, this third choice is likely to be used rarely in future, if ever, because it was added at least to legitimize some existing Crown leases which contained express provisions for storage rights and which were commonly referred to as "storage leases". In the absence of section 54.1 over the past decades, the department and its 
predecessors had attempted to grant storage rights by varying documents that were already in use, such as unit agreements and Crown leases, although their use was always questionable until section 54.1 was enacted. 